\section{Different sides of the sexes}

\section{Marian Dawkins}

The Female Animal. By Irene Elia. Oxford University Press: 1986. Pp. 319. £19.50.

Females of the Species. By Bettyann Kevles. Harvard University Press: 1986. Pp.254. \$20. To be published in Britain next month, £16.95.

THERE are some women who believe that biology places too much emphasis on the importance of male behaviour and male interests, brought about because so many biologists are men. Two such women who consider that the time has come to redress this imbalance and put the female point of view have independently written books which attempt to do just that. They cover much the same ground, and make many of the same points, but they do so in very different tones.

In The Female Animal, Irene Elia argues that the female role in reproduction, which has sometimes been seen as exploitation of females by males, should more properly be seen as female control. She argues that females and their nurturing, mothering qualities have dominated evolution and given rise to all the major evolutionary advances since the beginning of life on Earth. Females give their eggs food and shelter. By providing them with shells or nests, or ultimately retaining them in their own bodies, females enabled living forms to come out of the water. It was females, not males, that conquered dry land. And it was the care that females gave to their helpless young that eventually gave rise to the social communities of birds and mammals. The advantages of mothering and the demands of care and protection of the young led to the evolution of increasingly complex nervous systems, better senses to detect danger that might threaten the young and behaviour to feed and keep them warm. Eventually, argues Elia, the intelligence and cooperation which female mammals evolved for the extended mothering of their young led to all we regard as most worthy in human behaviour, unselfishness and moral altruism for example. Males are portrayed as the secondary sex, either as mere reproductive appendages like the male Holboell anglerfish, or fighters over

- Animal Behavior and its Applications, by Derek V. Ellis, is an account of "the daily activities of animals .... and how we as humans impact [sic] and manipulate those activities". The book is published by Lewis Publishers, 121 South Main Street, Chelsea, Michigan 48118, USA, and is distributed in Britain and the rest of Europe by John Wiley, Chichester, UK. Price is $\$ 29.95, £ 27.55$. valuable females or, at best, as following the female lead and caring for young themselves.

Elia makes her case forcefully, although many of her points, despite what she appears to think, are quite widely accepted. Few biologists would dispute the importance of maternal care or of female reproductive processes such as vivipary. Many field studies have now demonstrated the importance of female behaviour, including female competitiveness, in social structure. But Elia obviously feels that, to use her own words, the tale should be retold and that the call of "females first" needs to be reiterated more loudly and more clearly than it has been before.

She does this by documenting, group by group, the reproductive strategies to be found in various animals, with emphasis throughout on the female role. She then argues that, in humans, the domestication of plants and animals led to a crisis in the relation between men and women; what she calls the world's most mothering female became dominated by men who possessed the physical strength to secure by force both women and the fruits of the new agriculture. The book ends with these words:

since we became domesticators of plants and animals, we have been constrained to accede to and sometimes contribute to the use of force, surveillance, infanticide, marriage, incarceration, infibulation, and social-psychological conditioning to ensure that the amniotegestator-lactator legacy of female mammals be used at male behest.

This strident style detracts rather than adds to her case. And is marriage really to be seen as being to male advantage only? Is infanticide really imposed on females by males?

Using many of the same examples, but writing in a much more sober way, Bettyann Kevles also looks at evolution and courtship from the females' point of view. She, too, takes male biologists to task for their male-centred view. The exception, for her, is Charles Darwin, who Kevles praises for emphasizing the role of female choice. She describes the reproductive strategies of various species, the great variety of parental care and the even greater variety of roles that females adopt throughout the animal kingdom. She writes well, though most of her examples are to be found in standard textbooks on the subject. Like Elia, she is concerned to "tell the tale" again, through female eyes, but her treatment is altogether more balanced and she makes her points without antagonizing the reader. She also discusses what she calls "the other side of the coin" - the way in which females dominate other females and sometimes even kill their offspring. Females emerge from her book as just self-centred and manipulative of other individuals as males

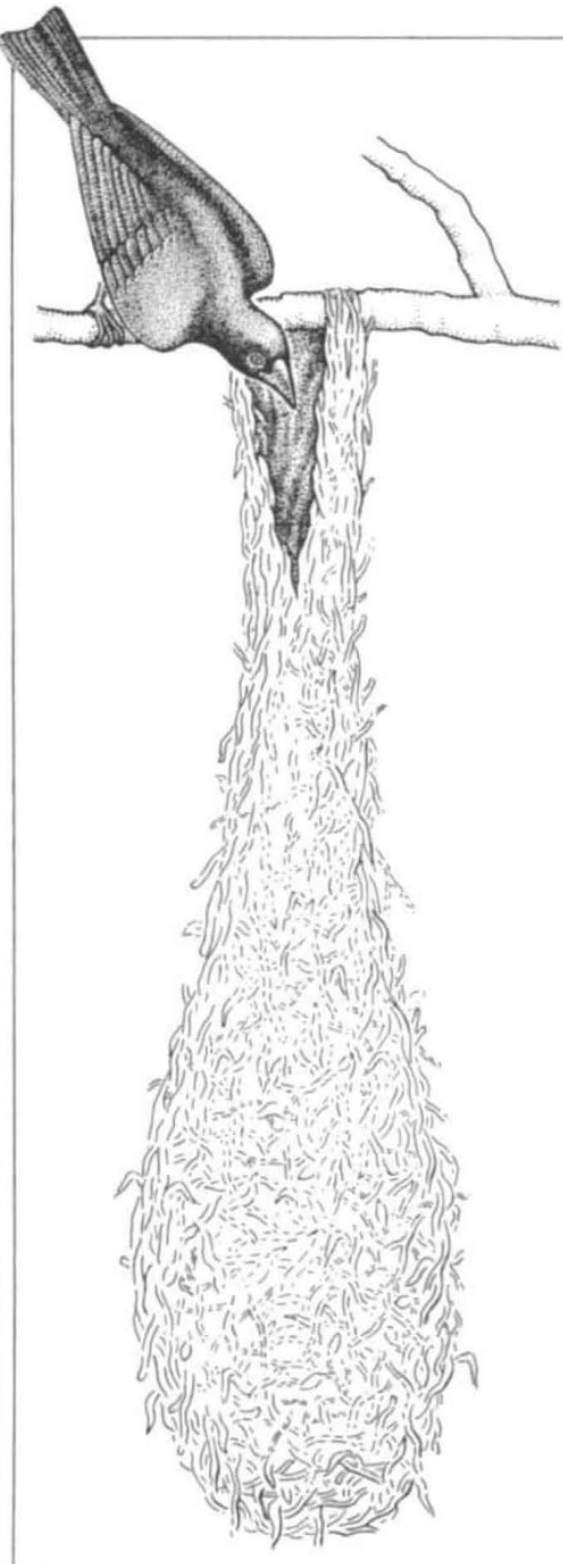

Devious female - a cowbird using the nest of the oropendola for her own eggs.

are. Females, for her, are equal players in the evolutionary game, neither controlling or controlled by males.

This view of an evolutionary balance between the sexes is far more convincing than Elia's picture of control and dominance by one or the other, but I have to confess to having had some difficulty in reviewing both of these books. Biology does not seem to be nearly as malecentred as Elia and Kevles think it is. Not just Darwin, but Fisher and more recently Lande, Zahavi and Hamilton, amongst others, have placed a great deal of stress on the importance of female choice and female behaviour, sometimes on very little evidence. If anything, it seems to me, female choice may turn out in the end to have been given too much prominence by biologists, rather than too little.

Marian Stamp Dawkins is Fellow in Biological Sciences at Somerville College, University of Oxford, Oxford OX2 6HD, UK. 